\title{
Development of Plant Based Larvicide and Herbal Mosquito Repellent Fast Card with Reference to Identification of the Functional Bioactive Compounds Effective Against Culex Mosquito
}

Amit Chattopadhyay ( $\nabla$ amitchattopadhyay1906@gmail.com )

Serampore College Arts Science and Commerce Departments

Vikky Shaw

Serampore College Arts Science and Commerce Departments

Piyali Mukherjee

The University of Burdwan

Subarna Ghosh

Serampore College Arts Science and Commerce Departments

Pranab Banerjee

Serampore College Arts Science and Commerce Departments

\section{Research Article}

Keywords: Duranta repens, green algae, plant extract, Culex sp., larvicide, fast card, active compound.

Posted Date: July 9th, 2021

DOI: https://doi.org/10.21203/rs.3.rs-673644/v1

License: @ (1) This work is licensed under a Creative Commons Attribution 4.0 International License. Read Full License

Version of Record: A version of this preprint was published at Applied Biochemistry and Biotechnology on January 26th, 2022. See the published version at https://doi.org/10.1007/s12010-022-03798-8. 


\section{Abstract}

Warm and humid climate creates ideal conditions for mosquito breeding. The ability of these vectors to spread a number of diseases to humans causes millions of deaths every year. Indiscriminate use of synthetic insecticides leads to the development of resistance in vector mosquitoes and along with this, these pesticides cause biological magnification of toxic components and affects adversely the non target organisms including human being. Commercially available, chemically manufactured mosquito repellent fast cards are convenient to use and quite effective but burning of such card generates a lot of smoke and might be hazardous to human health in long run. Thus, alternative approaches are to be adopted to control the population load of vector mosquito. The present study reveals the larvicidal effect of Duranta leaf extract against Culex mosquito. In addition to that mosquito repellent fast card has been developed by Duranta-algal mixture that has shown better result than commercially available fast card on the basis of mosquito mortality as well as the amount of gases emitted. Therefore, the active component of Duranta has also been investigated. In Duranta highest area percentage and peak have been shown by propeonic acid in the retention time 18.086 by GC-MS. So, it can be confirmed that the major active ingredient is propionic acid in Duranta which is responsible for the mosquitocidal properties. Occurrence of propionic acid in Duranta has also been confirmed by the HPLC analysis.

\section{Introduction:}

A number of diseases like Dengue, Malaria, Filariasis, Japanese encephalitis, West Nile fever are transmitted among humans and animals mainly by 4 genera of mosquitoes viz. Culex sp. Anopheles sp. Aedes sp. Mansonia sp [1, 2]. Hence, both vector and vector borne diseases have become challenging issues that have socioeconomic impact [3]. At present 120 million people are estimated to be infected with lymphatic filariasis caused by Culex sp. and approximately $80 \%$ of these populations are living in the tropical countries like Bangladesh, India, Indonesia, Mayanner, Nigeria, Philippines etc.

One of the major strategies is to use larvicides and adulticides to control the mosquito population. In general, chemical pesticides are recognized as the most worthwhile strategy for regulating mosquitoes. However, public concern has increased significantly regarding their negative impacts such as potential health hazards, water contamination, environmental pollution, toxicity to non target organism including man and the development of resistance in mosquito [4,5]. The Environmental Act (1960) has made rules and regulation to check the application of such chemical insecticides in nature. It has motivated the researchers to investigate for alternative approaches that would be environmentally sound, cost effective and target specific. A number of scientists have reported that plants contain a wide variety of potential phytochemicals which act as larvicidal agent (tannine, tarpeans, isoflavinoides) and these are generally target specific and eco-friendly as they are biodegradable $[6,7,8]$. Therefore, application of phytochemicals [9] for mosquito control is widely recognized. Present study evaluates the larvicidal efficacy of locally available botanicals like Duranta repens against the Culex larvae under controlled laboratory condition. It is known to us that 17 large trees are required to produce 1 ton of paper from virgin pulp, which leads to deforestation. There is a growing concern around the globe for preserving our forest reserves. Thus, use of non wood raw material is the demand of the century as it saves trees. Revival in homemade papermaking crafts paves the way to transform recycled waste into amazing prospects. Several scientists found algae as a potential cellulose fiber source, substitute to wood pulp owing to its low lignin content [10]. There is an invention that describes algal pulps, pre-pulps and paper products made there from (W01994004745A1 D21C). Chaudhari et al [11] described a method of production of fast cards using 400 GSM handmade papers with ayurvedic herbs like Nimbi, Tulsi, Haridr, Karpoor etc. Mosquito repellant gel and spray was prepared from various herbal formulations including that of Neem by Ranasinghe et al, 2016 [12] but as per our knowledge this is the first recorded description of production of fast cards against adult Culex that has been made from algal pulp containing added mosquitocidal properties of Duranta sp. As attention was given on the application of alternative strategies in the regulation of the population load of mosquito and emphasis was given on the system of IMM, IMM utilizes a collection of tools and strategies. The focus of IMM is to protect health of human from diseases caused by vectors like mosquitoes, maintain healthy condition of environment through suitable utilization and disposal of insecticides and improve the total condition of human life through rational and effective mosquito control strategies. Commonly the active toxic ingredients of plant extracts are secondary metabolites which are developed to defend the plant themselves from primary consumers or herbivores. These toxic phytochemicals have a number of physiological and biochemical targets in the insect body. These targets are proteins, nucleic acids and other cellular elements. This in turn, hampers normal physiological activities of insect body in different ways, the principal of which is the development of abnormality in the nervous system [13]. Therefore, in the present study the active ingredient of Duranta leaf extract has also been identified for its further use as Culex controlling agent. 


\section{Materials And Methods:}

The present experimental study was performed as follows:

\section{Preparation of Plant extract by percolation method}

The leaves of Duranta repens were collected from Serampore College campus. Leaves were air dried in shaded condition at room temperature for 7 days and after that powdered with a blender. The powder was preserved in glass jars for successive solution preparation. 3gm of powder was added in $50 \mathrm{ml}$ of ethanol in brown flask bottle and kept for 3 days and shaken the bottle once in each of the 3 days at room temperature. At the 3 rd day the mixture was filtered through whatman no. 1 filter paper. Then the yield \% and the concentration of the stock solution were measured. The remaining stock solution was refrigerated at $4^{\circ} \mathrm{C}$ until the subsequent larvicidal bioassay. In present study the calculation of yield \% is as follows-

Yield \% = total amount of plant material before percolation - total amount of plant material after percolation $\times 100 /$ total amount of plant material before percolation.

\section{Larvicidal efficacy test of plant extract on Culex larvae}

Larvae of Culex mosquito were collected from surrounding areas of Serampore College (22045/ N, 88023/ E) Hooghly, in early morning with small glass jars and transferred to the laboratory of Department of Zoology, Serampore College. Larvae were placed in a tray containing water. Afterwards $50 \mathrm{ml}$ of working solution was prepared from stock solution by following formula

$\mathrm{V} 1 \mathrm{~S} 1=\mathrm{V} 2 \mathrm{~S} 2$

Larvicidal activity i.e \% of larval mortality was calculated according to guidelines of WHO (2005) [14]. 25 larvae were released with the help of dropper into each tray. A control (ethanol only) tray was also included. Larvae were considered dead if they exhibited no sign of movement even after being touched with a glass rod. The \% of mortality was recorded after 24 hrs of larvicidal exposure.

The \% of larval mortality was corrected using Abbotts formula [15].

Corrected mortality $\%=\%$ mortality introduced $-\%$ mortality in control X 100

100 - \% mortality in control

\section{Preparation of algae mixture}

i. At first collected algae were cleaned in water and filtered. $180 \mathrm{gm}$ of the algae was taken in a mixer grinder with added water and beaten to make a bolus.

ii. Then algae bolus taken in a pan and boiled for $30 \mathrm{~min}$ on an oven. During this time period water was added for maintaining the liquid phase.

iii. $10 \mathrm{gm}$ of rice husk was added in pan which provided cementing property to the mixture.

iv. $10 \mathrm{gm}$ of saw dust was added with the boiling mixture to provide thickness property to the mixture.

In this mixture formation the ratio were taken is $90: 5: 5$ i.e in a $50 \mathrm{gm}$ algae mixture there is $40 \mathrm{gm}$ algae , $5 \mathrm{gm}$ rice husk and $5 \mathrm{gm}$ saw dust.

\section{Development of an anti mosquito fast card}

i. Algae mixture was cooled, after cooling; ethanol extract of Duranta leaf was added in the mixture. The mixture was then stirred for proper mixing and kept for 30 minutes. In the present study 50:50 ratio was taken i.e $50 \mathrm{gm}$ of algae mixture was added with $50 \mathrm{ml}$ of ethanolic plant extract.

ii. After that mixture was taken in Deckle and mould tray and excess water was drained. Then the algal mould was pressed in a hydraulic pressing machine with temperature controller to provide the proper shape.

iii. After that the final prepared fast card was subjected to subsequent bioassays. 
Test of efficacy of prepared fast card:

Bioassay was carried out in laboratory on adult Culex pipiens. 20 mosquitoes were released in two big bowls like jars by an aspirator. $1 \times 1 \mathrm{~cm}^{2}$ diameter Duranta ethanolic algae card were burnt and suspended inside the first jar and $1 \times 1 \mathrm{~cm}^{2}$ diameter commercial fast card was burnt in second jar and a thermocol piece was placed on each of the opening mouth of the jar. Cards were burnt slowly and smoke was released inside the jar. The process was allowed for 20 minutes, and then cards were taken out. Cotton mass soaked with sugar solution was placed inside the jar and the opening was covered by a small net and allowed for next $24 \mathrm{hr}$. After $2 \mathrm{hrs,}$ cotton mass was removed and behavior of mosquitoes was recorded in a note book.

\section{Evaluation of emitted gases by toxic indicator:}

Emitted gases from Duranta fast card and commercially available fast card were identified and evaluated by toxic indicator of Model PPMTM gaZguard Tx. [Fig. 1]

For investigating anti mosquito repellent fast card activity, the prepared card was checked for its flammability, burning efficiency with respect to burning time and eventually its effective repellent activity.

From the produced smoke, emission of $\mathrm{CO}_{2}, \mathrm{CO}$, and $\mathrm{O}_{3}$ were observed and recorded.

\section{Characterization of plant materials:}

\section{GC-MS study}

For GC-MS study the viscous dark mass of yielded plant product was dissolved in little quantity of chloroform and reduced to the volume of $2 \mathrm{ml}$. The dissolved $5 \mu \mathrm{l}$ sample diluted to $50 \mu \mathrm{l}$ and has been filtered with the help of High-Performance Liquid Chromatography technique and the component analysis has been done by GC-MS (GC) using TR-WAX MS column $(30 \mathrm{~mm} \times 0.25 \mathrm{~mm}$ ID $\times 0.25 \mu \mathrm{M} \mathrm{df}$, composed of PEG binding material, Polar column). Helium (99.99\%) was used as carrier gas. An injection volume of one $\mu \mathrm{l}$ was used (split ratio of $10: 1$ ). The oven temperature was set from $60^{\circ} \mathrm{C}$ (isothermal for two minutes), with a rise of $10^{\circ} \mathrm{C}$ per min, to $110^{\circ} \mathrm{C}$, then $5^{\circ} \mathrm{C}$ per min to $260^{\circ} \mathrm{C}$, ending with a $10 \mathrm{~min}$ isothermal condition at $260^{\circ} \mathrm{C}$. Mass spectra have to be taken at 70 $\mathrm{eV}$. Forty-nine minutes is the total running time for the study. Identification of the components was performed with the help of the datasheet of National Institute of Standards and Technology.

\section{HPLC analysis:}

Leaf extract of Duranta was further analyzed by a 'Hitachi Chromaster quarternary gradient reverse phase HPLC system' with 5160 pump, 5420 UV visible detecter for confirmation of the presence of Propionic acid. The extracts were filtered with syringe filter of 0.22 micron (High Media). The mobile phase for this experiment was prepared by mixing of $50 \%$ HPLC grade Acetonitrile (Merck) and $50 \%$ HPLC grade water (Merck) followed by filtering the mixture with solvent filtration system (Borosil). The other parameters of both the pump and detectors are as below:
a. Flow rate: $1 \mathrm{ml} /$ minute
b. Run time: 20 minutes
c. Absorbance range: $2 \mathrm{AU}$
d. Wave length: $210 \mathrm{~nm}$

\section{Observation and result:}

The present study on the plant extract has revealed the efficacy of Duranta repens as a potential mosquito larvicide. Table 1 depicts the impact of ethanolic extract of this plant on the mortality of third and fourth instar larvae of Culex sp after 24 hrs of larvicidal exposure. Ethanolic plant leaf extract at a concentration of 1000 ppm and 500 ppm shows $100 \%$ mortality of the studied mosquito larvae (Table1).

The present investigation also unfolds that the exposure of mosquitoes in Duranta extract- algae mixture card shows $100 \%$ knock down in first 20 minutes in comparison of $95 \%$ knock down by commercially available fast card. After 1 hour of exposure, the 
mosquitoes are treated with $10 \%$ of sugar solution on cotton wool and kept for $24 \mathrm{hrs}$ at $27+-2$ degree $\mathrm{C}$ and $80+-10 \%$ relative humidity. $70 \%$ mosquitoes became died and $30 \%$ showed knockdown. Contrarily commercially available fast card was responsible for $25 \%$ mortality, $65 \%$ knockdown (Table 2) and the rest $10 \%$ mosquitoes were active or in flying condition after this treatment with commercially available fast card.

During the burning of prepared card amount of some toxic gaseous products was considered. Result revealed that commercially available fast card discharged $2.20 \mathrm{ppm} \mathrm{CO}_{2}, 1.72 \mathrm{ppm} \mathrm{CO}$ and $1.73 \mathrm{ppm} \mathrm{O}_{3}$. On the flip side, released amount of gases from the prepared organic fast card were $0.79 \mathrm{ppm}, 1 \mathrm{ppm}$ and $0.48 \mathrm{ppm}$ respectively.

From the GC-MS analysis of the leaf extract the presence of 21 phytochemical constituents were revealed which are responsible for the larvicidal quality of the Duranta. The Propionic acid was the major bio active component of Duranta plant extract as it showed the highest area peak (49.70\%) HPLC analysis of Duranta was performed. The crude extract and fractions from Duranta plants was investigated for the presence of Propionic acid (Fig 3).

Figure 3 also represented that the component which appeared in the peak number five and investigated at 3.260 minute showed high similarity with the standard compound at 3.487 minute that confirmed the presence of Propionic acid in the Duranta leaf extract. Further study of the larvicidal bioassay of the pure Propionic acid in ethanol solvent showed that this compound is highly effective as they caused $100 \%$ mortality of the fourth instar larvae in comparison to $13 \%$ mortality caused by the solvent alone.

\section{Discussion:}

One of the most effective unorthodox approaches under the biological control programme is the exploration of the plant biodiversity to develop safer insecticides of botanical origin as a manageable and tenable method of mosquito control. In the current investigation, the ethanolic extract of Duranta repens shows $100 \%$ mortality of Culex larvae. Therefore, Duranta extract might be employed as a potent larvicide. Duranta repens are locally available also, hence provides means to protect the human health from vector mosquitoes. The ethanolic crude extract of Duranta leaves leads to $100 \%$ mortality of all instars (Culex pipiens) larvae at both $1000 \mathrm{ppm} \& 500 \mathrm{ppm}$ concentration. So, it can be presumed from the present study that the crude extract of Duranta leaves have larvicidal efficacy that can be used to reduce the population load of Culex vector. The Present experiment also reveals that prepared card from Duranta -ethanol extract with algae mixture possesses potentiality to be utilized as a mosquito repellent. On the basis of existing result, it can be inferred that such kind of organic fast card exhibits much better result in mosquito controlling methods and in addition, it causes insignificant hazard on human health than commercially available mosquito repellent fast card (Fig. 2). It is observed that, in the recent few years various Government sectors as well as non-Governmental organizations are coming forward to boost products and technologies that lead to the conservation of nature. Therefore, the fast card prepared in this research carries great promise in the coming days as an eco-friendly alternative to commercially available fast cards. This algal-Duranta fast card might also create a way of alternate livelihood generation specifically for the rural people. It can also be confirmed that the major active compound is Propionic acid, a naturally occurring carboxylic acid in Duranta which is responsible for both the larvicidal and adulticidal properties against Culex mosquito. Occurrence of propionic acid in Duranta was also confirmed by the HPLC analysis. From this study it can be concluded that leaves of Duranta may serve as new potential source of mosquitocide due to the presence of the abovementioned phytochemical constituents and the use of this plant extract as larvicide and in the preparation of antimosquito fast card may open a new avenue in reducing the mosquito population and the enormity of Culex borne diseases.

\section{Declarations}

\section{Acknowledgement}

The authors would like to convey wholehearted gratitude to Dr. Vansanglura, Principal, Serampore College for his motivation in this work. They are also indebted to Mr. Anit Kumar Chakroborty, Head, Department of Zoology, Serampore College, for his unceasing support and advice during the entire work. Authors are also thankful to Prof. Jai Prakash Keshari, Department of Botany, The University of Burdwan for his guidance in the development of herbal anti- mosquito fast card.

Funding: Not applicable

Conflicts of interest/Competing interests: No conflict of interest among the contributing authors. 
Availability of data and material: All data and materials generated or analyzed during this study are included in this published article.

Authors' contributions: Dr Amit Chattopadhyay and Dr Subarna Ghosh have developed and evaluated the efficacy of phytochemical as larvicide. Dr Amit Chattopadhyay along with Vikky Shaw and Dr. Piyali Mukherjee has produced the herbal anti-mosquito fast card and DR. Pranab Kr Banerjee has supervised the entire work and guided to prepare the manuscript.

Ethics approval: Not applicable

Consent to participate: Informed consent was obtained from all individual participants included in this study.

Consent for publication: The participants have given their consent to submit this manuscript in this esteemed journal.

\section{References}

1. Crans, W. J. (2004). A classification system for mosquito life cycles: life cycle types for mosquitoes of the northeastern United States. J Vector Ecol. 29(1), 1-10.

2. Arivoli, S., Tennyson, S., \& Martin, J. (2011). Larvicidal efficacy of Vernoniacinerea (L) (Asteraceae) leaf extracts against the filarial vector Culex quinquefasciatus(Diptera: Culicidae) J. Biopestic. 4 (1), 37-42.

3. Raveen, R., Kamakshi, K. T., Deepa, M., Arivoli, M., \& Tennyson, S. (2014). Larvicidal activity of Nerium oleander L. (Apocynaceae) flower extracts against Culex quinquefasciatus Say (Diptera: Culicidae). Int J Mosq Res. 1, 38-42.

4. Lee, S. E., Park, B. S., Kim, M. K., Choi, W. S., Kim, H. T., Cho, K. Y. ... Lee, H. S. (2001). Fungicidal activity of pipernonaline, a piperidine alkaloid derived from long pepper, Piper longum L, against phytopathogenic fungi. Crop Prot, 20, 523-528

5. Azmi, M., Naqvi, S. N. H., Akhtar, K., Moinuddin., Parveen, S., Parveen, R., \& Aslam, S. (2009). Effect of pesticide residues on health and blood parameters of farm workers from rural Gadap, Karachi, Pakistan. J Environ Biol, 5, 747-756

6. Joseph, M. K., James, M. M., Joseph, M. N., Mbaabu, M., \& Stephen, G. K. (2016). Phytochemical composition and larvicidal properties of plants used for mosquito control in Kwale County, Kenya. Int. J. Mosq. Res, 3(3), 12-17

7. Ravikumar, M. Y. S., \& Beula, J. M., S. and. (2013). Mosquito larvicidal activity of sea weeds extracts against Anopheles stephensi, Aedes aegypti and Culex quinquefasciatus. Asian Pac J Trop Dis, 3(3), 196-201

8. Nikkon, F., Zahangir, A. S., Hossain, K., Parvin, S., \& Ekramul, M. H. (2009). Larvicidal Effects of Stem and Fruits of Duranta repens Against the Mosquito Culex quinquefasciatus. Int. J. Pharmtech. Res, 1(4), 1709-1713

9. Ghosh, A., Chowdhury, N., \& Chandra, G. (2012). Plant extracts as potential mosquito larvicides. Indian j. Res, 135(5), 581-598

10. Mukherjee, P., \& Keshri, J. P. (2019). A Comparative Biomass Compositional Analysis of Five Algal Species from the Paddy Fields of Burdwan District, West Bengal, India, to Determine Their Suitability for Handmade Paper Pulp Formulation. Waste Biomass Valori, 10, 327-340

11. Chaudhari, C. D., Sumedh, S. J., Tanvi, S. J., Aishwarya, A. J., \& Vd.Mohan, R. J. (2016). Development and evaluation of efficacy of herbal mosquito repellent fast card. Int. j. Ayurvedic herb, 6(2), 2162-2165

12. Ranasinghe, M. S. N., Arambewela, L., \& Samarasinghe, S. (2016). Development of Herbal Mosquito Repellent Formulation. Int. J. Collab Res intern Med Public Health, 8(6), 341-380

13. Rattan, R. S. (2010). Mechanism of action of insecticidal secondary metabolites of plant origin. Crop Prot, 29, 913-920

14. World Health Organization Guidelines for laboratory and field-testing of mosquito larvicides. WHO/CDS/WHOPES/GCDPP/2005.

15. Abbott, W. S. (1925). A method of computing the effectiveness of an insecticide. J. Econ. Entomol, 18(2), 265-267

\section{Tables}

Table1: Efficacy test of plant extract on Culex larvae

Table2: Comparative analysis of effect of prepared fast card and commercially available fast card. 


\begin{tabular}{|c|c|c|c|c|c|c|}
\hline Mosquito & $\begin{array}{l}\text { Plant } \\
\text { extract }\end{array}$ & $\begin{array}{l}\text { Concentration } \\
\text { Ppm }\end{array}$ & $\begin{array}{l}\text { Total no. of larvae } \\
\text { introduce }\end{array}$ & $\begin{array}{l}\text { No. of dead } \\
\text { larvae }\end{array}$ & $\begin{array}{l}\text { Mortality } \\
\text { (\%) }\end{array}$ & $\begin{array}{l}\text { Corrected } \\
\text { mortality(\%) }\end{array}$ \\
\hline & Duranta & 1000 & 25 & 25 & 100 & 100 \\
\hline & $\begin{array}{l}\text { Repens } \\
\text { (leaf) }\end{array}$ & & & & & \\
\hline & & 500 & 25 & 25 & 100 & 100 \\
\hline & Control & 1000 & 25 & 4 & 16 & - \\
\hline $\begin{array}{l}\text { Culex } \\
\text { pipiens }\end{array}$ & $\begin{array}{l}\text { Ethanol } \\
\text { only }\end{array}$ & & & & & \\
\hline
\end{tabular}

\begin{tabular}{|c|c|c|c|c|c|c|c|c|}
\hline \multirow[b]{2}{*}{ Card name } & \multicolumn{3}{|c|}{ FIRST 20 MINUTE } & \multicolumn{5}{|c|}{ AFTER TREATMENT OF SUGER SOLUTION } \\
\hline & $\begin{array}{l}\text { Total no. of } \\
\text { introduced } \\
\text { adult } \\
\text { mosquitoes }\end{array}$ & $\begin{array}{l}\text { Time } \\
\text { of } \\
\text { exposure(minute) }\end{array}$ & $\begin{array}{l}\text { Initial } \\
\text { knockdown }\end{array}$ & Active & $\begin{array}{l}\text { Final } \\
\text { knockdown }\end{array}$ & $\begin{array}{l}\text { Finally } \\
\text { died }\end{array}$ & $\begin{array}{l}\text { Percentage } \\
\text { of } \\
\text { knockdown } \\
(\%)\end{array}$ & $\begin{array}{l}\text { Percentage } \\
\text { of } \\
\text { mortality } \\
(\%)\end{array}$ \\
\hline $\begin{array}{l}\text { Duranta- } \\
\text { algae mixture } \\
\text { fast card }\end{array}$ & 20 & 20 & 20 & 0 & 6 & 14 & 30 & 70 \\
\hline $\begin{array}{l}\text { Commercially } \\
\text { available fast } \\
\text { card }\end{array}$ & 20 & 20 & 19 & 2 & 13 & 5 & 65 & 25 \\
\hline
\end{tabular}

\section{Figures}

Fig1.

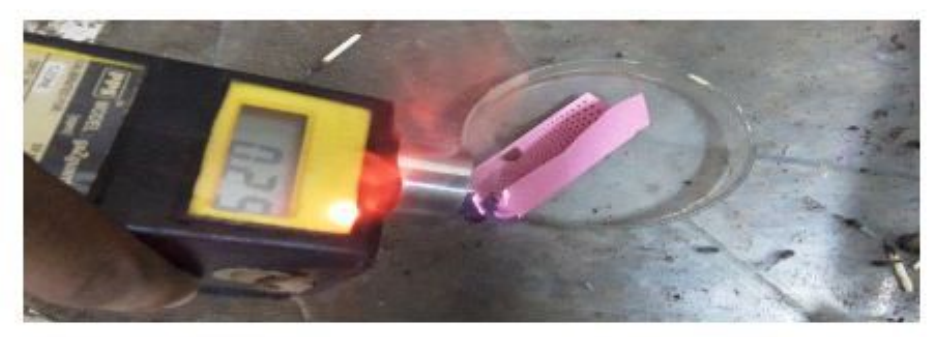

Figure 1

Identification of emitted gases by toxic indicator (gaZ guard Tx) 
Fig2.

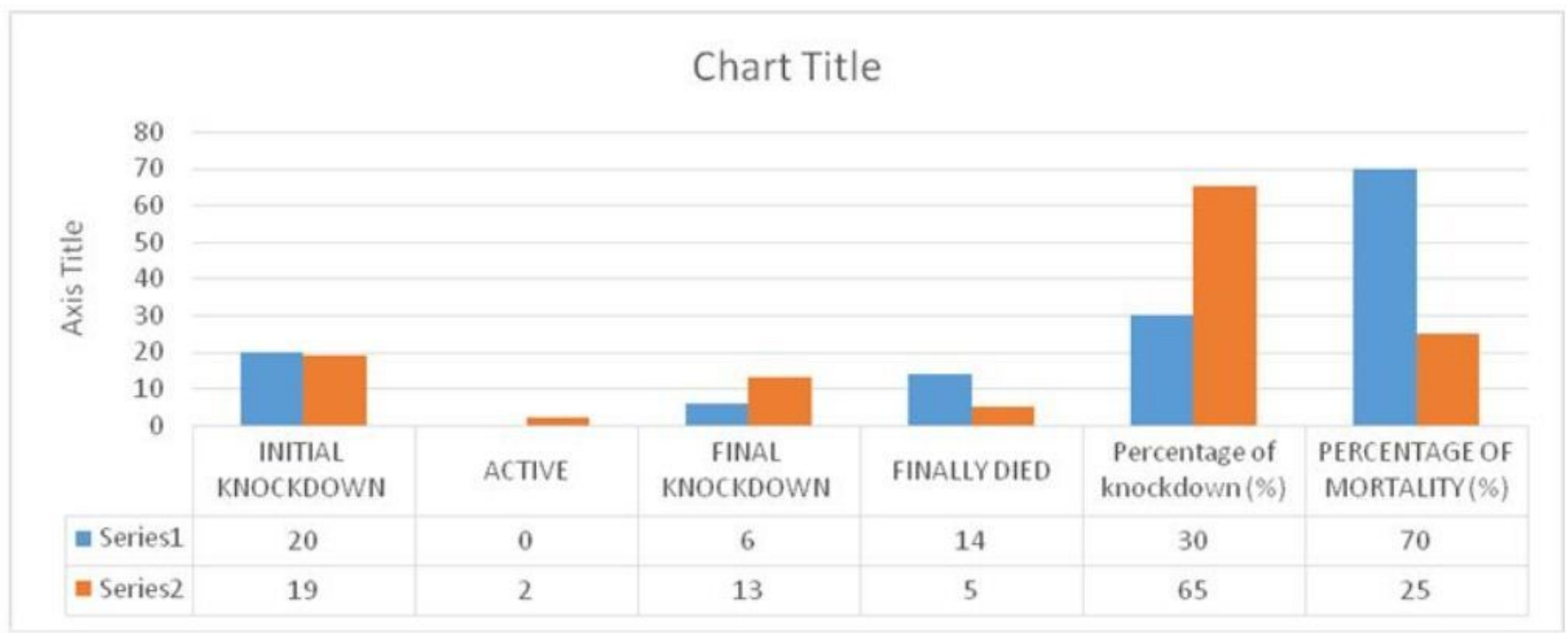

\section{Figure 2}

Graphical Representation of Effect of Two Anti-Mosquito Fast cards: a. Blue column represents the prepared organic fast card and b. Red column represents the commercially available fast card 
Fig 3.
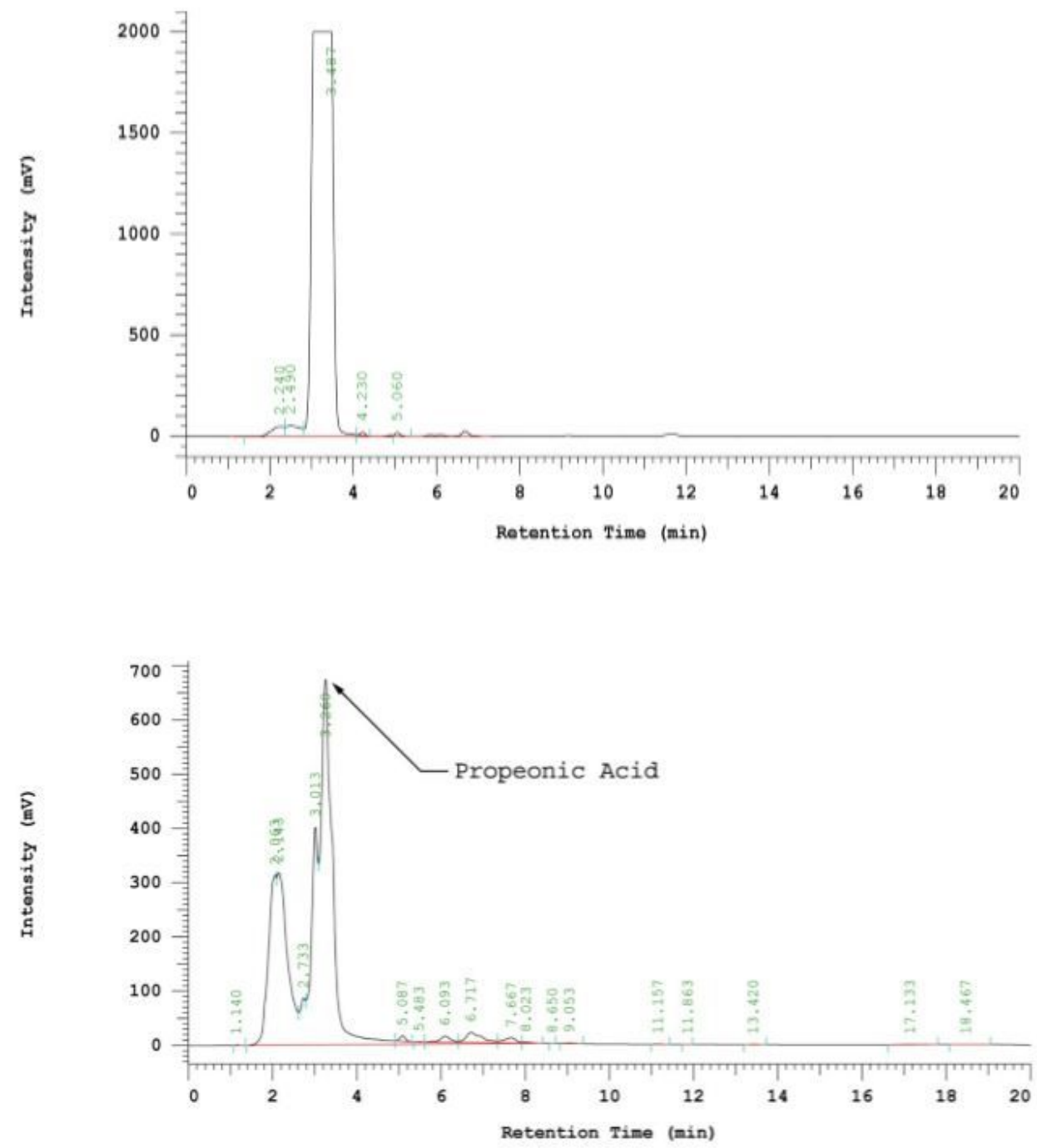

Figure 3

Showing comparative study between (A) the pure propionic acid (B) and the Duranta crude by HPLC spectral analysis 